\title{
SOVIET EMPLOYERS IN THE ILO: THE EXPERIENCE OF THE I930's
}

Since 1954 no question has so well succeeded in exacerbating the once rather staid proceedings of the International Labor Conference of the International Labor Organization as the problem of the status and rights of employer delegates from those countries which may be designated as "the states with fully socialized economies". "While David A. Morse, Director-General of the International Labor Office, was certainly correct in pointing out that "The ILO has always been confronted with political issues of one kind or another and [that] many of them have related to the representation of employers and workers within the Organization" 2, there is hardly any parallel in the history of the International Labor Organization for the fury of the debate over employer delegates from Communist countries which was unleashed when the Soviet Union rejoined the ILO in $1954 .^{3}$

It is not generally realized that the Soviet Union was a member of the ILO in the I930's and that precisely the same question over the status and rights of Soviet employers arose at that time. This paper will attempt to retrace the sequence of events in the 1930's and to show that the failure to settle the issue in a decisive way made possible a renewed outbreak of the dispute in the I950's.

1 C. Wilfred Jenks, The International Protection of Trade Union Freedom, London, Stevens \& Sons, 1957, p. $109 \mathrm{ff}$.

2 The International Labor Organization in a Changing World, in: Annals of the American Academy of Political and Social Science, Vol. 310, March 1957, p. 37. The impact on the ILO of the re-entry of the Soviet Union has been ably analyzed by Harold Karan Jacobson, The USSR and ILO, in: International Organization, Vol. XIV, No. 3, Summer r960, pp. $402-428$.

3 In this article the initials "ILO" refer exclusively to the International Labor Organization so as to avoid confusion with the International Labor Office, the secretariat of the ILO. 
The Soviet Union became a member of the League of Nations in September 1934. Its affiliation included the privilege of membership in the International Labor Organization. Choosing to exercise the privilege, the USSR participated in several ILO meetings between 1935 and 1937 . Such participation represented a radical change in policy, for hitherto the USSR had characterized the ILO as a capitalist inspired organization based on the unacceptable and doctrinally wrong principle of class collaboration. ${ }^{1}$ The new attitude toward the ILO was of course merely an additional manifestation of the radical turn in the international relations of the USSR which, in the face of the rapid rise and expansionist aims of the fascist powers under the leadership of Nazi Germany, resulted in a general rapprochement toward the Western democracies. Faithful to the exigencies of Soviet foreign policy, Communist parties sought to forge political alliances with socialist and other left-of-center groups, while separate Communist trade union movements merged with socialist labor federations, as in France, or simply disbanded in order to infiltrate other organizations, as in the United States.

The first Soviet delegation came to Geneva in June 1935 to attend the Igth Session of the International Labor Conference. It was, in ILO language, an "incomplete" delegation, for the government delegate was not accompanied by delegates representing the employers and workers of the Soviet Union. ${ }^{2}$

The following year the ILO held the exceptional number of three conferences. A regular International Labor Conference, the 2oth, met in June and was attended by a delegation from the Soviet Union which, in contrast to the previous year, now included a worker as well as a government delegate - thus still "incomplete" but only a step away from full tripartite representation. The worker delegate was accepted without challenge to his credentials. As a matter of fact, the Workers' Group in the Conference extended its welcome to him. ${ }^{3}$

1 Cf. Max Beloff, The Foreign Policy of Soviet Russia, I929-1941, London, Oxford, 2 volumes, Vol. I, pp. 197-198.

2 International Labor Conference, I 9 th Session, Proceedings, 1935.

3 In its report to the Conference, the Credentials Committee included a statement by the worker member of the Committee, speaking on behalf of the Workers' Group, in which he noted that "as a result of the entry of the Union of Soviet Socialist Republics into the International Labour Organization, the Organization has taken another step in the direction of universality, which is an important condition for the realisation of its aims. The arrival of representatives of the trade unions of the Union of Soviet Socialist Republics is a proof that the work of the International Labour Office is becoming in- 
Several months later, in October, two international labor conferences, the 2 Ist and $22 \mathrm{nd}$, met for discussions concerned with maritime labor problems. At this particular stage in the ILO's development, it had become a settled practice to convene occasional international labor conferences devoted solely to the establishment of international social policies protecting seamen and related maritime occupations. ${ }^{1}$ It was at these two conferences that the Soviet Union was represented for the first time by a "complete" delegation, with the employer's position occupied by Alfred I. Kaulin, ${ }^{2}$ Chief of the Central Maritime Services Department in the People's Commissariat for Water Transport. Since he was indubitably an official of a government agency and not, like other employer delegates at International Labor Conferences, a private employer or an official of an employers' association, a situation without precedent had suddenly though hardly unexpectedly arisen which in its wider implications raised fundamental questions about the tripartite structure of the ILO and its constituent bodies.

Confronted for the first time in over fifteen years with a threat to the homogeneity of its composition, the Employer's Group faced a real predicament. Had it chosen to overlook the presence of a Soviet employer, its silence might have been construed not only as an assent to the appointment of a completely different type of employer delegate but would aiso have tended to create a precedent for future conferences. Yet, if it had elected to enter a formal challenge to Kaulin's credentials, it would have had to do so in the setting of a special kind of International Labor Conference whose exclusive concern with maritime creasingly well understood. This statement is in accordance with the attitude of the Workers' Group and conforms to the point of view always expressed by the Group that the Workers' Delegation of each country should be constituted in such a way as to represent independent [sic] organisations of the working classes." (International Labor Conference, zoth Session, Proceedings, 1936, pp. 542-543.)

1 The last previous maritime conference, the I 3 th International Labor Conference, had been held in 1929. The need for holding two maritime International Labor Conferences in October 1936 resulted from a technical problem involving the application of Article is of the ILO Constitution. This article required the Director (now called the DirectorGeneral) of the International Labor Office to transmit the agenda of a forthcoming conference to the member states at least four months in advance of the beginning of the session. One important item not having been placed on the agenda of the 2 ist Conference by the Governing Body until June 22, I936, and thus coming too late for proper consideration at the session scheduled to begin on October 6, it became necessary to resort to the expedient of convening a separate 22nd Session for October 22, exactly four months after June 22, even though the 21st Conference would still be in session. In other words, two ILO Conferences met simultaneously to deal with the same substantive area of social policy. Both sessions adjourned on October 24.

${ }^{2}$ In some ILO documents the spelling of his name is Kaouline. 
matters made this assembly a singularly unsuitable forum for the resolution of a basic policy question. The employer representatives at the 2Ist and 22nd Sessions were mostly shipowners or shipping association representatives. They were specialists in maritime problems and not in the complexities of ILO procedures. Would it not be advisable, they may well have reasoned, to leave such an important issue, should it arise again, in the skilled hands of their own "professionals"? Was it not better handled by those of their colleagues who customarily attended the "regular" (non-maritime) ILO conferences and Governing Body meetings and who over the years had acquired an intimate familiarity with the workings of the ILO? For the less knowledgeable shipowners to have entered a formal challenge to Kaulin's credentials as an employer and to have pursued this challenge to an ultimate decision in the Conference certainly involved the risk not only of losing this particular case but also of jeopardizing future challenges under the ILO procedure governing objections to the credentials of delegates at International Labor Conferences. ${ }^{1}$

Eventually, the employers decided to make no direct attack on Kaulin's credentials. Instead, they sought to leave the question formally unresolved by having their representative on the Credentials Committee go on record with a statement that his constituents were "not perfectly satisfied about the validity of the credentials of certain Employers' and Workers' representatives." However, continued the statement, since the Employers' Group "did not consider it desirable to lodge any objection through the Credentials Committee it had asked that the Governing Body of the International Labour Office should consider the constitutional objections which... arose with regard to the Delegates in question."'2 Having been shown such a deceptively simple way out, the Conference approved the request for referral to the Governing Body forthwith. ${ }^{3}$ But to make quite certain that no doubts were left about the employers' deep concern, the chairman of the Shipowners Group addressed a letter to the president of the Conference for transmittal to the Governing Body.

This letter is the first major document in a controversy which has not even now, over 25 years later, been entirely resolved. It contains in

\footnotetext{
1 In 1932 the Standing Orders of the International Labor Conference, i.e. the rules governing conference procedures, had been changed "to provide that objections [to credentials] based on facts and allegations which the Conference, by a debate and a decision relating to identical facts and allegations had already discussed and recognized to be irrelevant or devoid of substance, should be irreceivable." (C. Wilfred Jenks, op. cit., p. IOS).

2 International Labor Conference, 2 Ist Session, Proceedings, 1936, p. 192.

3 Ibid., p. 7 o.
} 
essence the same critical views about the propriety of employer representation from countries with fully nationalized economies that have been unsuccessfully advanced in the period following Word War II to bar employer representatives of the Soviet Union and several other countries from accredited participation in tripartite ILO meetings. After first noting that a serious question involving fundamental principles had been raised by Mr. Kaulin's appointment, the letter continued in part as follows:

"We [the Shipowners' Group] consider it open to question whether the post [occupied in the People's Water Transport Commissariat of the USSR by Mr. Kaulin] complies with the criterion commonly applied to the concept 'employer' both in the spirit and the letter of the constitution of the ILO and in the juridicial systems which have so far operated...

Further, so far as the Shipowners' representatives are aware, the Russian Employers' Delegate has been nominated by the unilateral act of the Government and no [Russian] employers or employers' organizations have been consulted...

Should it be the case that Mr. Kaulin's functions are in fact those of a Government official, it will be apparent that the whole balance of voting in the Conference is upset. Nominations of this character would vitiate the tripartite nature of the Conference and would give an undue preponderance of votes to certain Governments."1

Precedents directly bearing on the substance of the issue did not exist. The framers of the ILO Constitution, bent on the establishment of a tripartite organization as a liberal capitalist response to the revolutionary forces at work in the world in 1919, had not envisaged the case of the monolithic state. Under paragraph s of Article 3 the member states committed themselves "to nominate non-Government delegates and advisers to attend ILO Conferences chosen in agreement with the industrial organizations, if such organizations exist, which are most representative of employers or workpeople, as the case may be, in their respective countries." The implied presumption of the independence of non-governmental delegates from control and direction by their governments was viewed as an essential support for the tripartite ILO structure. Article 4 explicitly provided, therefore, that "Every delegate shall be entitled to vote individually on all

1 The full text of the letter appears in Minutes of the $77^{\text {th }}$ Meeting of the Governing Body, November I 2-14, 1936, p. 204. 
matters which are taken into consideration by the Conference." Article 4 also included an important incentive for the presence at ILO conferences of "complete", i.e. tripartite, delegations by stipulating that if one of the member countries "fails to nominate one of the non-Government delegates... the other non-Government delegate shall be allowed to sit and speak at the conference, but not to vote."

While emphasizing these key elements in tripartitism, the Constitution supplied no definition of a bona fide employer or worker delegate. Instead, it vested in the Conference the power and responsibility to scrutinize the credentials of delegates and their advisers and to exclude, by two-thirds of the votes cast, any delegate whose nomination had not been made in accordance with Article $3 .{ }^{1}$ Because no employer delegate had ever had his credentials challenged prior to 1936, indirect substantive precedents could be found only, if at all, in the objections which had been lodged at every ILO Conference from 1923 onward against worker delegates from Fascist Italy and, at times, from other countries whose trade union movements had been absorbed into government labor fronts or had in some other way lost their independent character. ${ }^{2}$ Every challenge from the Workers' Group to the credentials of these government-controlled worker delegates had, however, come to nought against the combined opposition of employer and government delegates who justified their position on the ground that "there was in the country concerned no workers' organization other than that in agreement with which the delegate was in fact appointed which the government ought to have consulted in regard to the nomination of the delegate..." 3

1 Article 3, Paragraph 9. Challenges to credentials of delegates are considered in the first place by the Credentials Committee of the Conference, made up of one government, one employer, and one worker delegate. The Committee must decide whether an objection is receivable and, if so, whether it is well founded. Under rules adopted in 1932 and not substantially changed since then "a unanimous conclusion by the Credentials Committee that an objection is irreceivable is final; if the Credentials Committee does not reach a unanimous conclusion concerning the receivability of an objection the matter is referred to the Conference for decision without further discussion. A unanimous report by the Credentials Committee that an objection is not well founded is simply noted by the Conference; if the Credentials Committee or any member thereof submits a report advising that the Conference should refuse to admit any delegate or adviser, this proposal is submitted to the Conference for decision [by a two-thirds vote]." (C. Wilfred Jenks, op. cit., p. 93).

2 In this connection see especially Jenks, op. cit., Pp. 95-I05, Bernard Béguin, ILO and the Tripartite System, International Conciliation, No. 523, May 1959, pp. 405-426, and John E. Lawyer, Tripartitism in the International Labor Organization, unpublished manuscript prepared for a study group of the U.S. Government, August 16, 1956.

3 Jenks, op. cit., p. 104. See also Smith Simpson, The International Labor Organization: Retrospect and Forecast, in: Ințernational Conciliation, No. 369, 1941, pp. 326-327. 
When in 1932 French labor leader Léon Jouhaux, a member of the Commission on International Labor Legislation in 1919 from which the ILO had emerged, and the foremost spokesman of the Workers' Group at ILO conferences, once again lost a battle over an issue related to the bona fide character of the Italian worker delegate, he plainly showed his frustration by expressing the hope

“... that in the future the Soviet Union will adhere to this Organization and will send a complete delegation, including Government representatives and the directors of great Soviet industrial institutions. The Employers will refuse to accept these persons as representatives of employers, and then we of the Workers' Group will have a chance of adopting the same attitude as the Employers are adopting now."

To which he immediately added: "That, however, is not the way in which this Conference should work." ${ }^{1}$ H. C. Oersted of Denmark responded with some audacity for the employers that "in such a case, provided the individual were a genuine employer, we should be prepared to appoint him to Committees... So far at least as we are concerned, we are ready to accept a Russian employer and to consider his appointment to Committees." 2 The meaning of his statement was soon to be put to the test.

THE OFFICE NOTE

Only three weeks elapsed between the end of the 2 rst and 22 nd Sessions of the International Labor Conference and the beginning of

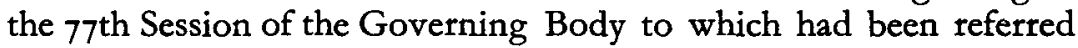
"the constitutional objections" that the Shipowners' Group had refrained from formally raising through the credentials procedure. "A question of so complex a character must obviously be studied at leisure", suggested Harold Butler, the Director of the International Labor Office, and he proposed that the Governing Body first "instruct the Office to prepare a note on the constitutional aspects of the problem, which would be placed on the agenda of the Seventy-eighth Session." The proposal was at once adopted, and no further discussion ensued. ${ }^{3}$

The Office Note was ready when the Governing Body convened

1 International Labor Conference, I6th Session, Proceedings, I932, p. 57.

2 Ibid., p. 59.

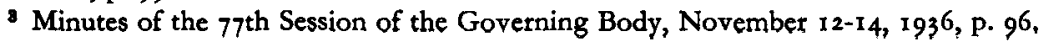


again in February 1937 for its 78 th Session, but for unstated reasons it was decided to postpone a general review of the issue until the 79th Seession. ${ }^{1}$ It may, however, be inferred that the decision to postpone was mainly a gesture of courtesy to the Soviet Union whose delegate on the Governing Body, Professor Boris L. Markus, was absent from the 78 th Session.

"The International Labour Conference is an assembly of a character which has no precedent in international law", began the text of the Office Note, and its tripartite structure "necessarily gives rise to certain problems of a practical nature." After a review of the circumstances which in the course of the 21 st Session of the International Labor Conference led to the fundamental question of employer representation, the Note addressed itself to the constitutional and political aspects of the question. Granting that "it may have appeared normal to consider the interests of the workers and of the employers as opposed the one to the other at the time when the International Labour Organisation was set up", the Note rejected the view that such opposition had either "the force of a permanent rule" or that it constituted "a basic principle".

"There is nothing in the basic principles of the Constitution of the International Labour Organisation which would seem to require that the employers for whose cooperation it provides should be considered as a 'class'. The social function of the employer may be carried out by a collective body (notably the State) just as well as by individuals. It can hardly be questioned that this function exists under a socialist as under a liberal system. The worker, from the very fact that he works, almost always has an employer; and that employer - whether a collectivity or an individual - has as such the tight to participate in the workings of the International Labour Organisation under the Constitution.

In the opinion of the Office there is only one condition which must be fulfilled in such a case; the competent authorities of the State must be sufficiently distinguishable to enable a distinction to be made between the Government and the State..."

The government, argued the Note, represented the interests of the community as a whole, but the state, while also including the government as such, comprised in addition various public services, such as railroads, which were increasingly being operated under public

1 Minutes of the 78 th Session of the Governing Body, February 4-6, 1937, p. 75. The text of the Note appears on pp. $160-163$. No further page citation to the Note will be made here. 
management in many countries. This distinction between state and government, found in all modern systems of public law, acquired a special validity in a socialist state, as represented by the USSR. Given that country's political and industrial form of organization, it "was therefore normal and natural that the employers' delegate of the Union of Soviet Socialist Republics should be an official of the State."

The thrust of the argument up to this point emphasized the functional view of the employer's role in industrial society and denied the test of private ownership as an essential definitional element. An additional consideration supporting the propriety of Soviet employer representation was discovered in the "permanent" character of the International Labor Organization. Employment of the expression "permanent" in the Treaty clauses establishing the ILO "shows that [ILO] activities are required to adapt themselves to all possible forms of the life of the nations, and cannot be hedged round with rigid and abstract formulae. The fact that the particular social organization of a State brings a new element into the working of the Conference does not in itself run counter to any principle of the Constitution."

For these fundamental reasons, concluded the Office Note, Mr. Kaulin's appointment, far from being an infraction of the Constitution, was "proof of the desire of the Union of Soviet Socialist Republics to give its collaboration [in the ILO] a character which was completely and absolutely in conformity with the rules laid down in the Constitution."

In taking such an outspoken position of advocacy on an issue of substantial importance for the future of the Organization the Office went well beyond the bounds which custom and prudence ordinarily impose upon the secretariats of inter-governmental bodies. The emphatic tone of the brief and the absence of all countervailing arguments were so far out of keeping with the usually bland character of Office documents that an explanation cannot be sought in the substance of the issue itself. As will later be pointed out, international developments at this time were seemingly leading the ILO into a stage of decline which had not been successfully stemmed by the belated affiliation of the United States in 1934. Under these circumstances to risk antagonizing the Soviet Union to the point, perhaps, of ending its participation and thus further weakening the ILO may have seemed a much greater danger than the threat to the principle of tripartitism. 
When the Governing Body gathered in May 1937 for its 79 th Session, Oersted, as the chief employer spokesman, had had time to prepare a refutation of the Note. He first embarked upon a review of the origins of the ILO to support his contention that the draftsmen of the Constitution had intended to establish a clear distinction between government and non-government delegates at International Labor Conferences: 'The term 'non-Government' was used in the actual text of the British proposals [in 1919]; this proved that there could be no question of anything but delegates independent of the Government to represent, respectively, employers and workers." 1 The whole notion of tripartitism rested, as he insisted, on independent employer and worker delegates free from government direction in expressing their views and casting their votes. In the absence of any reference in the proceedings of the 1919 meetings of the International Labor Commission to a distinction between government and state as separate entities - "a subtle and interesting distinction" but an indefensible one - the employers were compelled to conclude that the appointment of a state official as an employer delegate "was neither in conformity with the general principles nor with the text of the Constitution." 2

To resolve the issue Oersted outlined three alternatives. First, one could "pursue the matter to its logical conclusion, namely, to bring the matter before the Permanent Court of International Justice", since it wat this judicial body wich had been set up by the Treaty of Peace to deal with any difference of opinion, any difficulty and any question of interpretation." 3 There was, Oersted recalled, a precedent for such action. ${ }^{4}$ Secondly, it was at least conceivable that the ILO might wish

1 Minutes of the 79th Session of the Governing Body, May 6 to 8, 1937, p. 25. The published proceedings of Governing Body meetings carry very extensive summaries of the views expressed by speakers, and on occasion the summary is so complete that it borders on a verbatim stenographic record. Though the minutes axe invariably written in the indirect form of speech, it is frequently feasible to cite from them in the form of direct quotations.

8 Ibid., p. 27.

3 Ibid., p. 28.

- At the 3 rd Session of the International Labor Conference in 1921 the Netherlands Federation of Trade Unions and the International Federation of Trade Unions filed an objection with the Credentials Committee questioning the procedure employed by the Netherlands Government in nominating the Netherlands Workers' Delegate. By unanimous action the Conference adopted a resolution submitted by the Credentials Committee inviting the Governing Body to request the Council of the League of Nations to obtain from the Permanent Court of International Justice an advisory opinion as to the 
to "reconsider its constitution and to examine whether certain changes might not be desirable in order to bring it more up to date." ${ }^{1}$ However, employer support for such a move was neither promised nor refused. Thirdly, since it was not known "whether, at the next session or subsequent sessions of the Conference a so-called employers' delegate from the Union of Soviet Socialist Republics would be appointed", it might be possible to dispose of the issue by doing nothing at all, at least for the time being. Perhaps, as he implied, the Russians might even cooperate by not again appointing an employers' delegate. ${ }^{2}$

Jouhaux, of course, was not at all enthusiastic about the third alternative. Here, at last, was his long-awaited chance to impose an unwanted delegate upon the employers, just as they had each year forced one upon the Workers' Group. He began his reply to Oersted by expressing his surprise, so he said, that certain arguments advanced by the employers possessed a striking similarity to those which he himself had unsuccessfully submitted at previous sessions of the Conference. Had not the employers consistently rejected them? Had they not invariably voted in favor of seating worker delegates who represented only government-controlled labor organizations? 3 Turning to the question of qualifications, Jouhaux pointed out that a number of employer delegates were merely the paid officials of employers' associations and had few if any opportunities to function as employers. Whatever one might say about the Russian employer representatives, they at least were responsible for the operation of an enterprise. ${ }^{4}$

Judicial review, Jouhaux observed, had never been demanded by the Workers' Group for its own cases because the workers did not consider the Permanent Court competent to deal with the issue. If, however, such a step were now to be sought, the International Labor

propriety of the procedure employed by the Netherlands Government. The Court issued an opinion in 1922 which upheld the Government's action. (Permanent Court of International Justice, Series B, No. I, pp. 9-27, cited in Wilfred Jenks, op. cit., p. 96, note Is.)

1 Minutes of the $79^{\text {th }}$ Session of the Governing Body, op. cit., p. 28.

2 Ibid.

3 Ibid., pp. 28 and 38.

- Ibid., p. 29, Pierre Waline, a French employer delegate, who later became and still is a leading member of the Employers' Group in the Governing Body, took the occasion to defend the appointment of employers' association officials. (Ibid., Pp. 30-3I.) Although it was not at that time an important question, Jouhaux's argument was exhumed by the Soviet Union in the second half of the 1950's in response to employer attacks on the credentials of Russian employer delegates. See, for example, the remarks of A. A. Arutiunian, Soviet government delegate, in the Proceedings of the First European Regional Conference of the ILO, Geneva, 1956, p. I 10 (in French). 
Conference itself, rather than the Governing Body, would have to initiate the action since the Conference alone possessed the requisite authority. Were the case to go to the Court, the submission should be made in terms of the much broader question of the general qualifications of employers' representatives. Without necessarily rejecting eventual amendments to the Constitution, Jouhaux tartly observed that the Constitution had not been intended as an instrument for "checking social evolution" nor as "a bulwark of the present system of production." 1

Professor Markus' restrained statement furnished a sharp contrast to the remarks of the two spokesmen who preceded him. His country, he observed, had no responsibility for the tripartite structure of the ILO but was willing to respect it. Without expressing an opinion about the arguments advanced by the Office Note, he certainly agreed with its conclusion. If the Office view were not accepted, only two alternatives remained. Either the USSR changed its system, which would be a somewhat disproportionate sacrifice, or else the employers could try to deny the Soviet Union's right to be represented by complete delegations at International Labor Conferences. But "facts must be faced even if they were disagreeable." Whatever happened, the Soviet system was not going to be altered. ${ }^{2}$

At the conclusion of the debate Harold Butler intervened to support, first, Jouhaux's view that "the only body competent to deal with questions relating to the validity of the credentials of delegates to the Conference was the Conference itself." Since no formal protest had yet been lodged with the Conference, the Governing Body had really become involved, in a "very interesting, though perhaps somewhat academic, discussion." Nevertheless, so as to leave no room for doubt about his own position, Butler warned that it would be "extremely dangerous to go behind the word 'employer' and try to limit it to certain kinds of employers." An employer was merely one who provided employment in return for remuneration, regardless of any other considerations. This was the essential element. "The right course was to hold strictly to the terms of the Constitution, which simply referred to employers and workpeople without making any further distinction." 3

At this point the Governing Body terminated the inconclusive exchange of views and proceeded to the next item on its agenda.

1 Minutes of the 79th Session of the Governing Body, op. cit., p. ${ }^{8}$.

2 Ibid., p. 30.

3 Ibid., pp. 39-40. 
INTERIM COMPROMISE

When the $23^{\text {rd }}$ Session of the International Labor Conference opened on June 3, 1937, less than four weeks after the "academic" discussion in the Governing Body, the delegation of the Soviet Union at first did not include an employer delegate. For several days the Employers' Group and everyone else may well have believed that the issue had rather easily resolved itself, at least for one year. But in its third report to the Conference on June Is, 1937, the Credentials Committee announced that the Soviet Union had after all appointed an employers' delegate, Mr. Nicolas Andreev, the director of a Moscow textile factory, and so the issue was joined once again. ${ }^{1}$ Whether Andreev's late nomination was a tactical move to forestall an anticipated challenge to his credentials can only be a matter for conjecture. The Employers' Group in any case had made advance preparations. A lengthy memorandum had obviously been drafted well beforehand. Setting forth a detailed and carefully organized account of the basic objections of the employers to the appointment of a Russian employer delegate, it was annexed to a letter to the president of the Conference in which the Employers' Group indicated that it was "prepared to refrain from asking the Conference to settle immediately the question relating to the validity or invalidity of the credentials of Mr. Nicolas Andreev" if the Conference would agree to request the Governing Body to bring the question before the Permanent Court for an advisory opinion. ${ }^{2}$ It is evident that the Employers' Group had thus decided not only its strategic objective (a decision by the Court) but also its bargaining position (no formal challenge in return for assurance of judicial consideration).

In subsequent off-the-record discussions, the employers were apparently soon forced to make one crucial concession. As appears quite clearly from the official report of the Credentials Committee to the Conference, Oersted agreed to an arrangement whereby the Governing Body would again be asked to "examine thoroughly the problem raised by the creation of a new economic system which the authors of the Constitution could not foresee" and would be left free to "adopt any measure which it considers necessary or appropriate for the settlement of this problem." 3 To this recommendation the Conference readily gave its approval. In fact, it did so without in any

1 International Labor Conference, 23rd Session, Proceedings, 1937, Third Report of the Credentials Committee, p. 542.

2 Ibid., Seventh Report of the Credentials Committe, pp. $550-554$. See also p. 362, note 4.

3 Ibid., p. 550. Emphasis supplied. 
way discussing the substance of the issue. ${ }^{1}$ It would therefore seem that the employers in effect surrendered their chance for a judicial determination, for without a prior Conference recommendation that the issue be referred to the Court in the Hague, the Governing Body clearly retained full freedom of action in every respect.

Why then did the employers agree to such a bad bargain? The probable answer is that the alternative was even less attractive to contemplate. Had they pressed a formal objection to the point of a vote in the three-member Credentials Committee of the Conference, such a vote would in the first place have turned on the issue of receivability. ${ }^{2}$ In this case the worker member, Léon Jouhaux, and the government member, Paal Berg of Norway, probably would have joined to declare the objection irreceivable. Given a split vote in the Committee, the Conference would then have been asked to express itself first on the issue of receivability alone, and it is very likely that the Committee majority would have been upheld. Even if in some unexpected way the question of receivability had been decided in favor of the employers, the Credentials Committee was certain to be split on the substance of the objection itself. Following a predictably divided committee report, it would have been quite impossible to have found the required two-thirds vote in the full Conference to reject Mr. Andreev's credentials. An adverse vote would, in turn, have created a precedent jeopardizing the success of challenges in future years under possible more auspicious circumstances. ${ }^{3}$ An adverse vote would also have been preceded by a discussion embarrassing to the employers. Jouhaux and several of his colleagues in the Workers' Group would not have hesitated to bring up again the history of fifteen years of unjust treatment of their objections against the Italian worker delegate in order to ridicule the employers' challenge to the credentials of the Russian employer delegate. Given all these unfavorable contingencies, the compromise may not have seemed quite so ill-conceived as long as some chance remained of getting to the Court through the Governing Body.

THE SECOND DEBATE IN THE GOVERNING BODY

The first meeting of the Governing Body after the close of the 23 rd Session of the Conference in June took place in October 1937.

1 Ibid., pp. 468-469. A letter by Professor Markus briefly setting forth the position of the USSR appears on p. 554 .

See P. 358 , note 1 .

3 See p. 356, note 1 . 
Mr. Frederick William Leggett of Great Britain, newly elected chairman, suggested that in view of Professor Markus' absence the controversial issue be held over to the next meeting, i.e. until February I938. Thereupon Oersted at once made a successful counter-proposal to refer it instead to the Standing Orders Committee of the Governing Body. ${ }^{1}$

This was a very shrewd tactical move indeed. The tripartite composition of the Governing Body, based on a ratio of $2: 1$ : I, allocated to the employers 8 seats as against 8 seats for the workers and 16 for the representatives of governments. But in the committees of the Governing Body, representation and voting were based on full equality of the three groups. Consequently, in the fifteen-member Standing Orders Committee Oersted could start off with five employer votes to make up one-third, rather than one-fourth, of the total needed for a vote favorable to his side. In addition, he required only three more out of the remaining ten government and worker votes to be able to report back to the Governing Body with a majority recommendation to refer the issue to the Court. Such a recommendation would not have been binding, to be sure, but it would have carried a psychological weight and a moral authority which could not have been disregarded. As it turned out, he almost succeeded. The five worker representatives on the Standing Orders Committee, as he may perhaps have known, were split!

From Oersted's point of view an unfortunate delay of almost four months intervened before the Standing Orders Committee actually met to take up the question of the Soviet employer delegate. In those fateful days, the danger of an approaching war increased month by month as the League of Nations demonstrated its utter weakness in the face of Germany's imminent threat to Austria's independence, Mussolini's adventure in Ethiopia, and Japan's aggressive actions in the Far East. Anxious to shore up the crumbling international structures erected after World War I, the Western democracies were less and less disposed to antagonize an uncertain but potential ally, the Soviet Union, over what must have appeared then as a relatively minor matter. Also, with more and more nations leaving the ILO, the time was singularly unsuitable to initiate a course of action which might have impelled still another country to recon-

\footnotetext{
1 Minutes of the 81 st Session of the Governing Body, October 6-9, 1937, p. 16. The representative of the Soviet Union did not attend any further meetings of the Governing Body until the USSR left the ILO.
} 
sider its relationship with the ILO and beyond that, with the whole League of Nations system. ${ }^{1}$

It was in these circumstances that the Standing Orders Committee met on January $3 \mathrm{I}, 1938$, to take up the question. Harold Butler, mindful of his grave responsibility for the continued functioning of the ILO, made no secret of his concern and pleaded that the "Committee would therefore have to consider very seriously whether it was an opportune moment for opening a general discussion on the very wide constitutional problem raised in the report of the Credentials Committee." 2 Paal Berg, Norwegian government representative, supported him and recalled his "impression that the Credentials Committee had felt that extreme caution should be exercised before any definite decision was taken." ${ }^{3}$ Instead of referring the matter to the Court at this time, Berg proposed that the Governing Body content itself with making a report to the next (the 24th) session of the International Labor Conference in June 1938 which "could discuss the whole question on the basis of that report" and "might decide that there was no question to refer to the Court." 4 Carter Goodrich, representing the United States government, also thought that the question was "both very difficult and delicate" and expressed the hope that there would be no decision to refer the question to the Court at this particular moment. ${ }^{5}$

With all five government delegates lined up against him Oersted had to look toward the workers' representatives for the three votes he needed. It is amazing that he managed to get two: Corneille Mertens of Belgium and Charles Schürch of Switzerland. Mertens had not forgotten that "when in the past the workers had protested against the credentials of certain delegates, the employers had not supported them." That, however, was no reason, he maintained, why he should

1 The first country to leave the ILO, and of course the League of Nations, was Nazi Germany (in 1933). Italy announced its withdrawal from the League and the ILO in December 1937, shortly before the crucial meeting of the Standing Orders Committee of the Governing Body. A number of Latin American countries announced their departure from the League system at about this time. Guatemala, Honduras, Nicaragua, Paraguay, and El Salvador coupled their withdrawal from the League with termination of membership in the ILO. More important countries, however, like Chile, Venezuela, Argentina, and Brazil decided to retain their ILO affiliation. (See ILO, Official Bulletin, Vol. 22 (1937), p. 184; Vol. 23 (1938), pp. 103, 107, 125,127 ).

Minutes of the Standing Orders Committee of the Governing Body, January 31, 1938, p. 4.

8 Ibid., p. 6.

Ibid.

5 Ibid., p. 7. 
not support them now in what he considered to be a legitimate claim. ${ }^{1}$

Two supporters were not quite enough. Gunnar Andersson of the Swedish Federation of Trade Unions (LO), Joseph Hallsworth of the British TUC, and even Robert Watt of the American Federation of Labor associated themselves with the five government delegates when the decisive test question was eventually put to a vote in these terms:

"Should the following question be referred by the Governing Body to the Permanent Court: Was the nomination of Mr. Nicolas Andreev, non-Government delegate, as employers' representative at the Twenty-third Session made in conformity with the provisions laid down in Article 389 of the Peace Treaty?"

\section{The vote was 8 to 7 for rejection. ${ }^{2}$}

The issue now having been decided, it was next resolved by I I votes and 4 abstentions to recommend to the Governing Body that a summary report be prepared for submission to the 1938 Conference. The report "would be limited to a brief statement of the procedure followed [in the Governing Body] and the conclusions arrived at and would not discuss the substance of the question." 3

Indicative of the increasing concern over the political ramifications of the issue was the fact that when a few days later the Standing Orders Committee placed its recommendation before the Governing Body,

1 Ibid., p. ro. In a communication of November 14, 1958, Professor Carter Goodrich of Columbia University, who served as U. S. Labor Commissioner in Geneva at that time and who represented the United States government on the Governing Body, wrote to the author: "Of the two workers you have voting for the motion, Mertens was particularly passionate in his anti-communism because his daughter had married a communist, and Schürch was Swiss and my recollection is that Switzerland and Russia had no diplomatic relations."

2 Ibid., p. I 2. Article 389 formed part of that portion of the Treaty of Versailles which established the International Labor Organization (Part XIII). Specifically, it laid down the rules governing representation at the Conference. For an analysis of the formal status and numbering system of the ILO Constitution see The Future Development of the Constitution and Constitutional Practice of the International Labor Organization: Memorandum by the Legal Adviser of the International Labor Office, in: [the ILO's] Official Bulletin, Vol. 27, No. 2 (1945), pp. I 14-1 I6.

3 Minutes of the 82nd Session of the Governing Body, February 3-5, 1938. Report of the Standing Orders Committee, Appendix I, p. 13, of the confidential minutes of the Fifth (Private) Sitting. 
it did so behind closed doors. ${ }^{1}$ Oersted fought to the end to bring the issue before the Court. In his final appeal to the Governing Body he argued that the proposal of the Employers' Group could not be rejected because Article 37 of the ILO Constitution clearly stipulated that any question or dispute relating to the interpretation of the Constitution should be placed before the Permanent Court. Ernest Mahaim, the Belgian government representative on the Governing Body, a member of the 1919 International Labor Commission, and an internationally recognized authority on the ILO, even conceded that it would not be possible "to avoid recourse to the Permanent Court sooner or later." All things considered, however, "the present was not a suitable time for the Governing Body to embark upon that procedure." 2

It remained for Vaclav Nemcek, a worker deputy member of the Governing Body from Czechoslovakia, to give expression to a view which may well have been shared by the members of the Governing Body. At "a time when several States in succession had left the International Labour Organisation..." he questioned "whether it was an expedient moment to take a step which might cause the Union of Soviet Socialist Republics to consider leaving the Organisation... If the employers' group really meant well by the International Labour Organisation... it would do better to avoid raising the question at the present time and to reconsider the whole matter with reference to its industrial and political aspects." 3

Thereupon the Governing Body voted, 20 to 8, to adopt the recommendation of its Standing Orders Committee not to refer the issue to the Permanent Court and thus wrote an end to an important chapter in the history of the International Labor Organization. As a final step, the $24^{\text {th }}$ Session of the International Labor Conference in 1938 was duly apprised in the sketchiest possible terms of the action taken by the Governing Body, ${ }_{4}^{4}$ but the proceedings of this Conference

1 The matter was discussed at the Fifth (Ptivate) Sitting of the Governing Body which dealt ostensibly with the report of the Finance Committee, an item invariably discussed in executive session. (See Minutes of the 82 nd Session of the Governing Body, op. cit., p. 58.) But the full report of the Standing Orders Committee shows that the "question of the nomination of an employers' delegate by the Union of Soviet Socialist Republics" w as discussed at this particular sitting. (Ibid., p. 72 and Appendix V, p. 123, footnote 1 ).

Minutes of the 82nd Session of the Governing Body, op. cit., Report of the Standing Orders Committee, Appendix I, p. 8 of the confidential minutes of the Fifth (Private) Sitting.

3 Loc. cit.

4 International Labor Conference, 24th Session, Proceedings, 1938, p. 468. The report, as drafted by the Office, was adopted by the Governing Body without comment. (See Minutes of the 83rd Session of the Governing Body, April 28-30, 1938, pp. 33 and 94-95.) 
are devoid of any indication that the uninformative communication was so much as acknowledged. The Soviet Union sent no delegation to this meeting. As a matter of fact, the Soviet Union, expelled from the League of Nations in December 1939 over the issue of the war with Finland, attended no further meetings of the ILO until its re-affiliation under vastly changed circumstances in 1954 .

\section{CONCLUDING OBSERVATIONS}

The preceding review of the course of events has raised several questions requiring further comment. In the first place, it may be asked why the employers pressed so strongly for judicial review of the issue by the Permanent Court of International Justice instead of choosing a more frontal attack through a formal challenge of the Russian employer's credentials. The answer rests, it seems, on the employers' assumptions that they would have lost their fight in the Conference - a very safe assumption - and on the supposition that the Court would have been more amenable to their arguments than the representatives of governments and workers. It is of course quite impossible even to speculate what the Court would have decided if it had been asked to rule on the question. A strict construction of the ILO Constitution might have led the Court to rule for the employers, but it is also conceivable that in the setting of the times the Court would have been persuaded by the arguments set forth in the Office Note. In any event, the employers realized correctly that their only tangible chance of success rested on a judicial instead of a political determination, based on an examination of the intent of the ILO's founders.

Lacking the gift of foresight, the employers had over the years greatly weakened the moral, if not the legal, basis of their case by their consistent support of the credentials of worker delegates clearly subject to government direction and equally clearly objectionable to the Workers' Group. Moral weakness went hand in hand with political ineptness. In the framework of the ILO's internal political structure, in which the votes of government representatives equal the combined votes of workers and employers (assuming "complete" delegations), only a firm worker-employer understanding could have ensured for the two non-government groups a decisive role in determining their own composition. By their past shortsighted actions the employers had deprived themselves of this opportunity long before the issue over the credentials of Russian employer delegates ever arose. Seen in this light, their defeat in the 1930's was only a down payment of the price they had to pay. The balance was collected after 1954 , when the USSR again joined the ILO. 
That a certain spirit of retaliation motivated some of the leading worker representatives is beyond doubt. Nor must it be forgotten that the mid-1930's were almost everywhere a period not only of unemployment and impoverishment but also of turbulent labormanagement relations from which the ILO itself could not be insulated. As already noted, independent Communist labor movements had given way earlier in the decade to the dictates of worker unity, and Communist parties had shifted their tactics from vituperative competition with socialist organizations to collaboration in the Popular Front. The predominantly socialist convictions of the ILO worker representatives constituted, in these circumstances, another factor militating against worker support of any action which threatened the new unity. In addition, the workers' representatives in the ILO probably had quite another reason for keeping the issue away from the Permanent Court. Judicial tribunals they generally regarded as unsympathetic, if not downright hostile, to their views and aspirations. In the only case involving disputed credentials that had reached the Court, the decision had gone against the complaining worker organizations. ${ }^{1}$ While this did not constitute conclusive evidence about the Court's outlook, it is likely to have strengthened their resolve against recourse to the Court, especially since they knew that the employers were certain to lose their case in the ILO's own credentials procedure.

The main motives which impelled the governments to oppose the employers have already been indicated. They were strictly of a political nature, intimately connected with the ever more threatening world situation. To antagonize the USSR in the ILO over a relatively inconsequential issue appeared to be out of all proportion to the principle involved and to the potential risks. The chief danger to world peace was Nazi Germany, not the Soviet Union. The latter was, hopefully, an ally. The danger of Communist expansion must at that time have seemed so ridiculously small that it merited no consideration in policy formulation. Had not Stalin's slogan "socialism in one country" carried the day against Trotsky's theory of "permanent revolution"? This was, therefore, no time for offending a country whose then still recent entry into the League of Nations and the ILO had been an unexpected but welcome event holding much promise for continued normalization of relations between the USSR and the West. It may also be surmised that the traditional reluctance of governments to submit their own disputes to an international judicial forum played a role in their determination to delay a litigious settlement of

1 See p. 362 , note 4 . 
the question as long as possible and then, when a decision had become unavoidable, to block the referral to the Court.

Forced to make the unpleasant choice between tripartitism in the traditional sense and the universality of the ILO, the sentiments of the International Labor Office understandably favored universality with its implications for organizational growth and increased influence. But one of the most surprising aspects of the whole episode is the unequivocal stand of the Office in favor of accepting the credentials of the Russian employer representative. No one who has looked into the record of the I950's, when the question once again arose, can fail to be impressed by the complete absence of a formal Office point of view in the later period, and by the carefully cultivated appearance of official neutrality. To maintain that the future of the ILO in the 1930's was by no means fully assured, whereas two decades later it had demonstrated its viability as the only institution created at Versailles to survive World War II, provides certainly a part of the answer, but only a part.

In the 1930's, by contrast with the 1950's, the Office was unlikely to provoke strong resentment in one bloc of nations or another for expressing its point of view on this issue because there was at yet no cold war, no East-West conflict, and no world-wide division between two rival economic and political systems against which its position would have been appraised. Nor was there any significant disagreement among the governments on the issue. It was, therefore, relatively safe for the Office to follow its natural preference and to be ranged in this question against the employers. It should also be noted that Albert Thomas, the first Director of the International Labor Office and Harold Butler's immediate predecessor, had established a policy of Office initiative and position-taking which was rather at variance with the code of prudent neutrality and anonymity fostered by the Secretariat of the Leage of Nations. ${ }^{1}$ And finally, there was a major difference between the position in the 1930's of Harold Butler, the one-time British civil servant, who had been with the Office from the very beginning as 'Thomas' first assistant, and the position in the 1950's of David Morse, the former United States Under-Secretary of Labor, for

1 See E. J. Phelan, Yes and Albert Thomas, New York, Columbia University Press, I 949, especially pp. 247-256. Cf. also John S. Gillespie, The Role of the Director in the Development of the International Labor Organization (Unpublished Ph.D. Dissertation), Columbia University, 1956; Smith Simpson, op. cit., pp. 321-322; and Carter Goodrich, The ILO: A Going Concern, in: Annals of the American Academy of Political and Social Science, Vol. 246 , July 1946, Pp. 114 -I 15 . 
whom official neutrality in such a delicate issue involving the USSR had to be a prime requisite.

On balance, then, the forces compelling a stand by the Office proved immeasurably stronger than those favoring neutrality. Yet, even the Office opted for delay rather than decisive action whenever the possibility to postpone consideration offered itself, and there can be no doubt that, if there had been any opportunity of avoiding the decisive vote in the Standing Orders Committee of the Governing Body, Butler would have seized it.

One of the notable facets of the unfolding story is the exceedingly passive position of the USSR whose appointment of an employer representative was after all responsible for the tempest. Beyond one dispassionate speech by Professor Markus in the Governing Body and a remarkably brief letter of his, setting forth the position of the USSR, no further steps were taken by that government to secure the rights claimed for Soviet employer representatives. Such astonishing restraint may well have been the result of supreme confidence in the outcome, based on an awareness that the USSR could not possibly improve upon the position staked out for it by the workers, the governments, and the Office. Equally likely, however, is the supposition that the USSR was essentially indifferent about the result, as shown by its decision, possibly taken as early as the summer of 1937 , to abandon all further active participation in the ILO. What effect a more timely awareness of this decision would have had in changing subsequent developments is difficult to estimate. Most likely, the issue would at once have been dropped from further consideration and the Governing Body would have been spared its final closed debate and the exasperatingly close vote in the Standing Orders Committee. But there is a slight chance that it might have served, instead, to change one crucial vote in the Standing Orders Committee, followed perhaps by a Court test with interesting consequences for the I950's.

In any event, it seems established beyond question that the decision of the USSR not to participate further in the work of the ILO had nothing at all to do with the outcome of this case, for the outcome was favorable to it. Since this decision, then, did not hinge on the issue of employer representation but depended on other, far weightier, considerations, one is left to wonder what finally remained of the compelling political arguments which rested on the dangers of antagonizing the Soviet Union by questioning the credentials of its employer representatives.

1 See p. 366 , note I. 